\title{
S6 - Estabilización de lixiviados generados en el relleno sanitario La Chureca de la ciudad de Managua
}

\author{
Henry J. Vilchez \\ Peogeama de Investigación de Estudios Nacion ales y Servicios del Ambiente, \\ Universidad Nacional de Ingeniería, Managua, Nicaragua
}

*Autor al que se dirige la correspondencia: jvil12p@gmail.com

\section{Resumen}

T a investigación logra establecer que son muchas las variables que condicionan el proceso de descomposición Lde los residuos, siendo la variable fundamental al estudiar la degradación en el relleno y la naturaleza de los desecho. Se realizó una caracterización de su composición química y física, características difíciles de conocer en detalle y establecer con seguridad una descripción matemática del residuo, por la naturaleza heterogénea de los vertidos de la ciudad de Managua. Para el caso del relleno sanitario La Chureca, se estableció un monitoreo en los datos químicos y físicos del lixiviado para un período de febrero a octubre del 2014, para conocer el comportamiento del lixiviado de manera que los datos fueran contrastados con otras investigaciones. Es concluyente el resultado que las concentraciones alcanzadas oscilan en una composiciones de lixiviado propia de vertederos maduros, coincidiendo con otras investigaciones realizadas en esta temática siendo la diferencias el tiempo en que se logra dicho fenómeno. Se denota que la relación DBO5/DQO está a menudo en el rango de 0.05 a 0.2, datos típicos que se esperan de los rellenos sanitarios que están en esta fase metanogénica, demostrando de esta manera que la dinámica del vertedero analizado es una fase madura así como de difícil biodegradabilidad. Por lo que de acuerdo a la investigación, la fase de maduración alcanzada está enfocada en la duración del estado inestable del lixiviado que es de corta duración logrando una estabilización en un año y medio.

Palabras claves: Lixiviado, DQO/DBO5, Estabilización, Relleno sanitario.

\begin{abstract}
$\mathrm{R}$ esearch can establish that there are many variables that determine the decomposition process of waste, being fundamental to study the degradation in the filling and the nature of the waste variable, so we proceeded to perform a physical and chemical characterization of the composition, characteristics difficult to know in detail and establish security in order to describe mathematically the waste, due to the heterogeneous nature of the discharges from the city of Managua. In the case of La Chureca ladfill, chemical and physical data was monitored in leached for a period from February to October 2014, established to understand the behavior of leached so that the data were contrasted with other research. It is concluded that result oscillate in concentrations achieved in the compositions of mature landfill leachate, coinciding with other research in this field being the differences in the time that such a phenomenon is achieved. It denotes that the BOD5/COD is often in the range of 0.05 to 0.2 , typical data expected from landfills that are in the methanogenic phase, thus demonstrating that the dynamics of the landfill is analyzed as mature so biodegradability is difficult. According to this research, it reached the maturation phase is focused on the duration of the unstable state of the leachate that is short lived achieving stabilization in a year and a half.
\end{abstract}

Keywords: Leachate, COD/BOD 5, Stabilization Landfill 